\title{
Causes of Decreased Discharge and Damage to a Dewatering Well's Gravel Coat
}

\author{
Krzysztof Polak $^{1} \cdot$ Karolina Kaznowska-Opala $^{1} \cdot$ Katarzyna Pawlecka $^{1}$
}

Received: 9 March 2014/ Accepted: 29 July 2015/Published online: 8 August 2015

(c) The Author(s) 2015. This article is published with open access at Springerlink.com

\begin{abstract}
Drainage wells used in lignite mining have to be operated at high efficiency in order to achieve a targeted drawdown in the shortest time period possible. However, oversizing of pump units and excessive pumping can cause accelerated aging of wells and over time, decrease a well's drainage efficiency. This article analyzes the case of a well that was operated for 10 years and then abandoned at a lignite mine. A common practice in installing dewatering wells in Poland is to protect the well screen with a prefabricated granular layer (called a "gravel coat") that is attached to the screen when it is lowered into the hole. The combination of the gravel coat and well screen is surrounded by a protective gravel pack. Samples of the gravel coat were obtained from the abandoned well. The percentage by weight of precipitates in, and the porosity of the gravel coat from the abandoned well were determined and compared with the properties of new gravel coat material. Tests were conducted in the laboratory to compare hydraulic losses, apparent seepage velocity, effective velocity, and the hydraulic efficiency of the well's gravel coat. The results of the tests explain the low hydraulic efficiency of the abandoned well and the origin of the damage to the gravel coat. The actual yield was also
\end{abstract}

Krzysztof Polak

kpolak@agh.edu.pl

Karolina Kaznowska-Opala

kazn@agh.edu.pl

Katarzyna Pawlecka

pawlecka@agh.edu.pl

1 Department of Surface Mining, Faculty of Mining and Geoengineering, AGH University of Science and Technology, Al. Mickiewicza 30, 30059 Kraków, Poland compared with the calculated theoretical safe yield, which was estimated based on the results of geological records from the construction of the well.

Keywords Well efficiency · Clogging - Groundwater . Discharge rate $\cdot$ Well damage $\cdot$ Lignite mining

\section{Introduction}

Over time, the efficiency of dewatering wells is known to decrease (Gonzalez 2013). The decrease of a well's yield can be due to a number of factors, such as technical failure in the pumping equipment, or reduced permeability of the pre-fabricated granular layer (called a "gravel coat") that is attached to the screen when it is lowered into the hole. Periodic replacement or renovation of the pumping equipment is necessary and relatively easy. However, drainage wells in lignite mines can age relatively rapidly (Weidner et al. 2011) and it is much more difficult to recover losses associated with such aging of wells. The flow reduction associated with well aging is often due to clogging of the filter and the well screen. The clogging can be due to various factors: chemical (caused by precipitation of various compounds such as calcium carbonate and iron precipitates), biochemical (due to bacteria causing chemical reactions, precipitates, and organic fouling), electrochemical (due to the formation of an electrostatic potential difference during the flow of water on the filter surface), and mechanical, due to fines movement and compaction caused by the flow of water (de Zwart et al. 2006; Driscoll 1995; Houben and Treskatis 2007; Kasenow 2001; Treskatis et al. 1998).

Depending on the type of clogging (Fig. 1), different well components can be impacted. For example chemical clogging most commonly affects the gravel pack and well 
Fig. 1 Two major types of well clogging

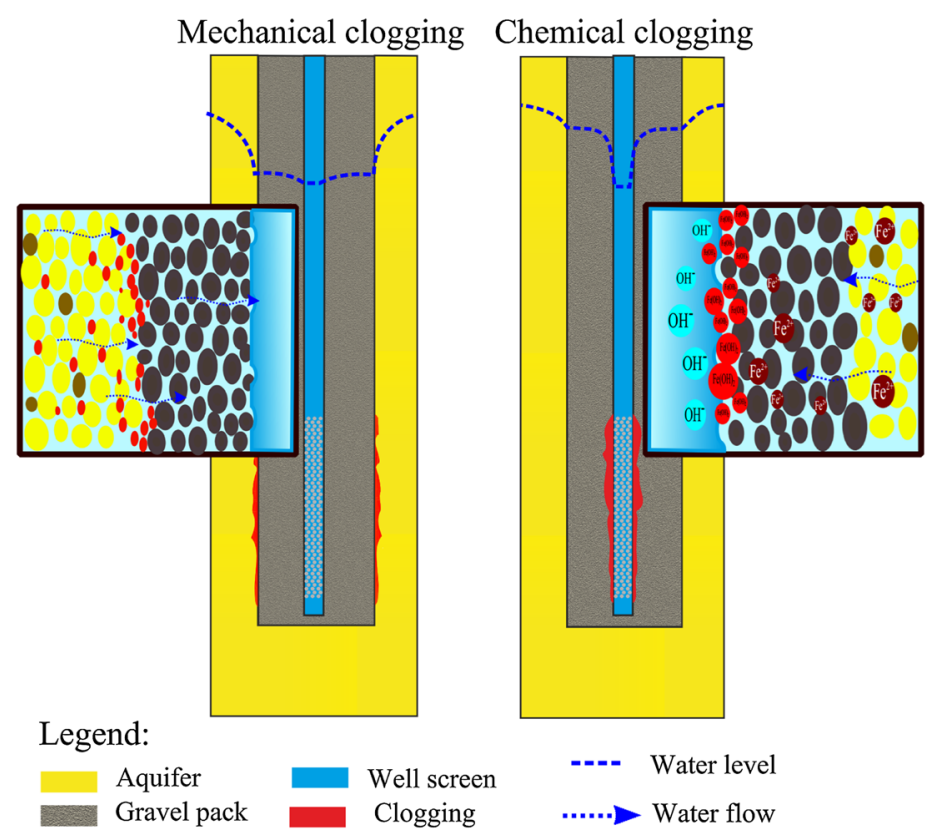

screen. In contrast, mechanical clogging is more likely to affect the zone adjacent to the well (de Zwart 2007).

Groundwater level fluctuations and oxidation of iron compounds can cause mechanical clogging by iron oxyhydroxide flocs. This can limit a well's operation by reducing the durability of the filter or blocking well screen voids. These processes decrease flow into the well screen and increase hydraulic resistance in the flow path and, consequently, they reduce well yield (Houben and Treskatis 2007). As clogging develops, effective velocity through the filter increases if the pumping rate is maintained. Intense exploitation of a well can damage the filter and lead to suffusion as well as sanding up of the well, and consequently rapid wear of the pump.

In European open-pit lignite mines, it is common to install well casing with gravel coats pre-installed around the well screen. There are a number of ways in which the gravel coats are manufactured. For example, in Germany, a layer of gravel coat is glued onto the well screen, In Poland, gravel coats consist of gravel manufactured in a tube-shape form that is slid over and secured around the well screen. After the well screen and pre-formed gravel coat are installed in the borehole, the gravel pack is poured around the installed casing and gravel-coated screen in the normal manner. Key features of such a well's components are illustrated in Fig. 2.

\section{Background}

Water inflow to a well depends on many factors, including: the hydraulic nature of the aquifer, the movement of groundwater, hydrodynamic conditions in the well,

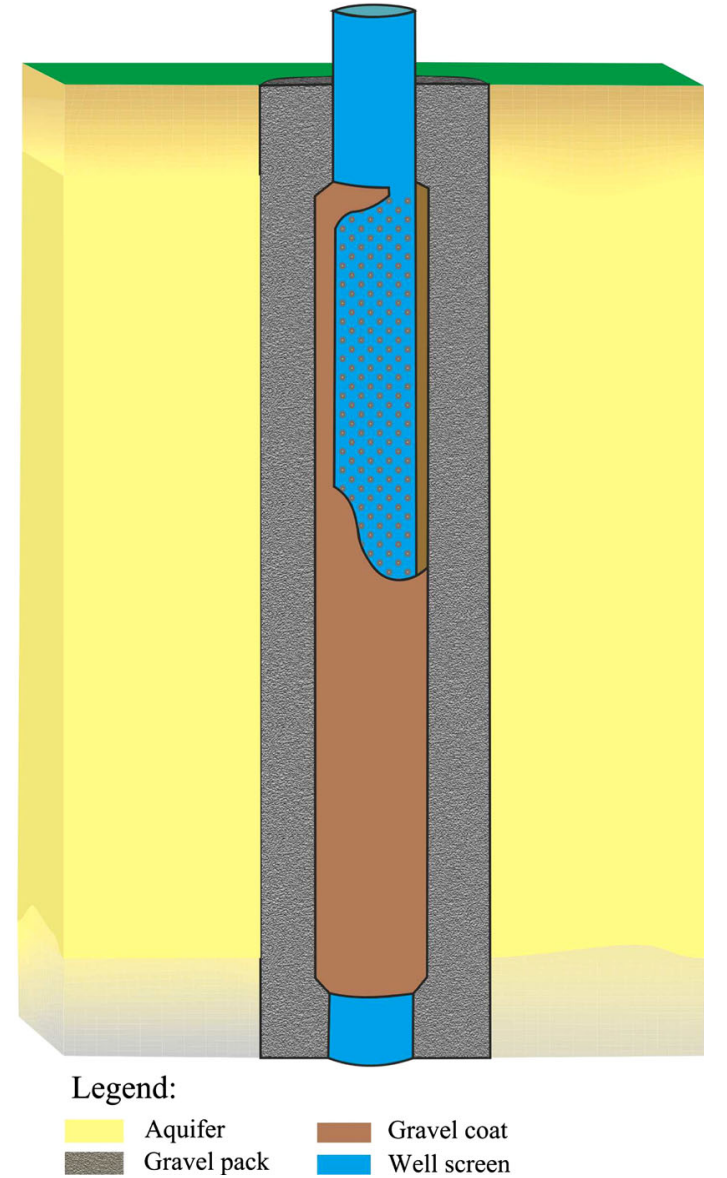

Fig. 2 Key features of the well

interaction with other wells, supply conditions, and the extent of the aquifer. Calculations of inflow to a well usually do not completely describe the actual conditions of 
Fig. 3 Theoretical safe and actual yield of the W105 well

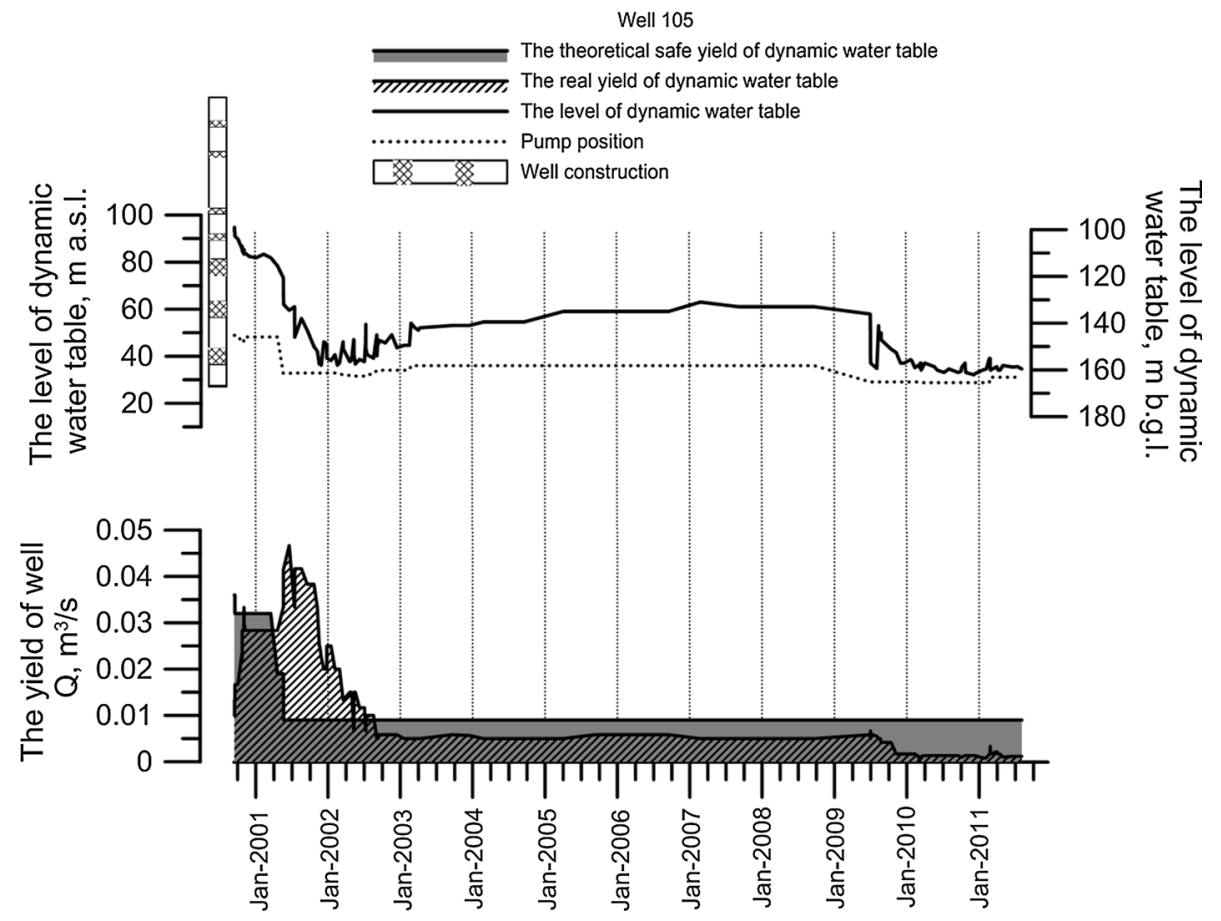

groundwater flow. In this study we used the computational Dupuit flow diagram (Mishra and Kuhlman 2013).

An important parameter in well yield calculations is the maximum inlet flow velocity, which is the maximum flow velocity of groundwater at the external surface of the filter. Determination of maximum inlet flow velocity is complex. Normally, for simplicity, the permissible inlet velocity is assumed to be dependent on the coefficient of the hydraulic conductivity of the filter zone, which is often determined in the laboratory. However, laboratory results are approximate and may differ substantially from actual values. What's more, the theoretical maximum inlet velocity can change during the operating life of the well, due to the aging processes previously mentioned. Increased hydraulic losses through the filter zone are directly linked to a reduction of the well's yield. When the amount of water pumped out of the well does not decrease despite aging processes impacting the filter-zone, then the inlet flow velocity must increase. This may shorten the well's life span, due to corrosion, clogging, and sanding up of the well.

There are several formulas that can be used to calculate the maximum inlet flow velocity. The most popular are Sichardt's and Abramov's formulas and the Gross' criterion (Kovacs and Ujfaludi 1983; Williams 1981). These formulas can be used to calculate the theoretical safe yield. The safe yield of a well depends on the active filter surface and the maximum inlet flow velocity. Differences between the theoretical safe and actual yield of the well are illustrated in the example of well W105 (Fig. 3).
In order to assess the operating conditions accurately, the theoretical safe yield was calculated and compared with the actual yield. For this purpose, Abramov's formula (Dimkic et al. 2008) for the maximum velocity of water entering the filter was used, as follows:

$v_{\lim }=\frac{\sqrt[3]{K}}{30}$

where $K$ is hydraulic conductivity of the aquifer, $\mathrm{m} / \mathrm{s}$.

For the calculations, the hydraulic conductivity of the aquifer was varied along the length of the filter zone. Mean hydraulic conductivity values for the different strata were selected based on publications by Sawicki (2000) and analysis of the well's hydrogeological profile. W105 had multiple filter zones at various levels. Therefore, lowering the water level affected the length of the active filter zone, and decreased, the theoretical safe yield. The graph (Fig. 3) shows the theoretical safe and actual yield plus the position of the water table expressed in meters above sea level (masl) and meters below ground level (mbgl) over the life of the well.

Analysis of the charts indicates that when the drawdown of water level in the well is increasing, the well's yield is decreasing. In the initial phase of operation, the actual yield exceeded the theoretical safe value. During 2001 and 2002, the well was pumped at more than the safe yield; this is considered to be a major reason for the disintegration of the gravel pack and the well screen gravel coat, as discussed later. 
Well W105 was operated in a lignite mine for about 10 years, from 2001 to 2011. During abandonment of the well, it was discovered that a defective gravel coat caused the well to sand up and rapid wear of the pump. To help evaluate potential influences and the physical and chemical processes on the aging of drainage wells, a sample of water was taken from well W105 during operation. The water sample was analyzed in the mine laboratory; a list of selected measured parameters is shown in Table 1.

Water from well W105 had weak alkalinity, average electrical conductivity (EC), and elevated total hardness $\left(\mathrm{Ca}-\mathrm{HCO}_{3}-\mathrm{SO}_{4}\right)$. Compared to background water quality (Zdechlik and Kania 2003), the W105 water sample was clearly distinguished by elevated concentrations of $\mathrm{SO}_{4}$, $\mathrm{Fe}, \mathrm{Mn}, \mathrm{Ca}$, and $\mathrm{HCO}_{3}$. These components can occur at high concentrations due to the dissolution of iron sulphide oxidation products.

The breaks in well operation led to oxidation of iron sulphide minerals, increased sulphate concentrations, and groundwater acidification Neutralization of acidic water by carbonate rocks in the aquifer also took place, leading to increased $\mathrm{Ca}$ and $\mathrm{HCO}_{3}$ concentrations (Singer and Strumm 1970; Vandersalm et al. 2013). Well W105 was equipped with several filter sections, so the water inside the well comes from different aquifers. The neutralization process could have continued inside the well due to mixing of waters from different aquifers. However iron floc, formed as a result of iron oxidation, could be observed in water pumped from the well. Also, when the well was exposed, iron oxides were found deposited between the well screen and gravel coat and in the pores of both the gravel coat and the gravel pack.

\section{Methodology}

During the dismantling of well W105 (Fig. 4) at the working level of the pit, disintegration of the screen's gravel coat was discovered. This helps explain the cause of frequent pump unit failures, due to solids getting into the well. A 2-3 mm thick layer of ochre was found at the inner surface of the gravel coat (Fig. 5b).

To determine the cause of mechanical damage to the well, samples were taken from the gravel coat and compared with a sample from new material (Fig. 5a). For simplicity, the gravel coat samples were designated as "OLD" and "NEW".

A static leaching test was carried out to investigate the differences in chemistry between the old and new gravel coat materials. After grinding both the old and new gravel coat material to gravel, $100 \mathrm{~g}$ dry weight samples were prepared and mixed with distilled water at a 1:10 ratio. The solution was then stirred on a laboratory shaker for $24 \mathrm{~h}$.

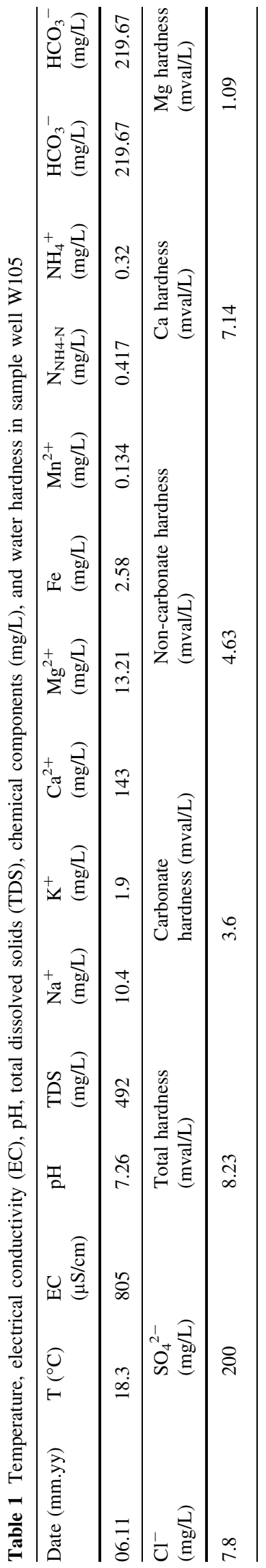




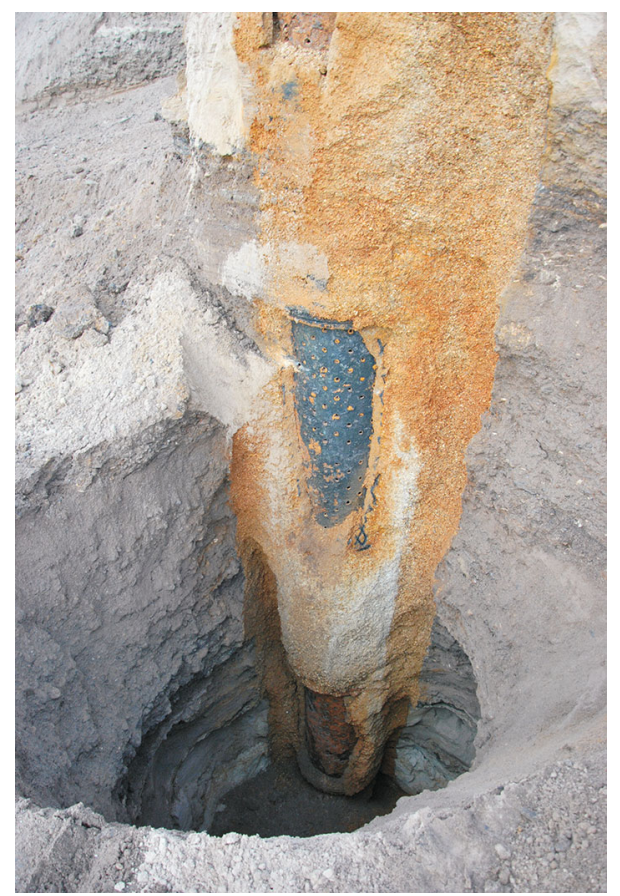

Fig. 4 Well W105 (2011-09-30)

Water extracts were analyzed at the Hydrogeochemical Laboratory, AGH University of Science and Technology in Cracow (Poland). The concentrations of mineral components were measured using a spectrometer atomic mass detector ICP-MS (Elan 6100, Perkin Elmer) and an emission spectrometer with inductively coupled plasma ICPOES (Optima 7300DV, Perkin Elmer). The results are presented in Table 2.

Next, the porosity of both gravel coats were examined. The weight of the samples was measured in water and air. Porosity was calculated using the following formula:

$n=\frac{m-m_{A}}{m-m_{W}} \cdot 100 \%$

where $m$ is the mass of sample in the air, $m_{A}$ is the mass of gravel skeleton, and $m_{W}$ is the mass of sample in the water.

The total porosity was 21.3 and $7.8 \%$ of the new and old gravel coat, respectively. Microscopic inspection of the gravel coat indicated that the filter was clogged by both iron compounds and silicates.

In order to assess the hydraulic parameters of the old and new gravel coat, hydraulic tests were conducted in the Laboratory of Hydrology and Geohydraulics, AGHUniversity of Science and Technology in Cracow (Poland). Figure 6 shows a schematic of the test apparatus. Samples of gravel coat were cut to fit the shape of the measuring apparatus and placed in the container. To stabilize the inflow, a $4 \mathrm{~mm}$ size gravel pack was placed against the upstream surface of the gravel coat. Water was pumped from a reservoir through the system and the flow $Q_{P}$, inlet pressure $P$, and pressure drop $\Delta P$ across the filter sample container were measured every $5 \mathrm{~s}$. Measurements were
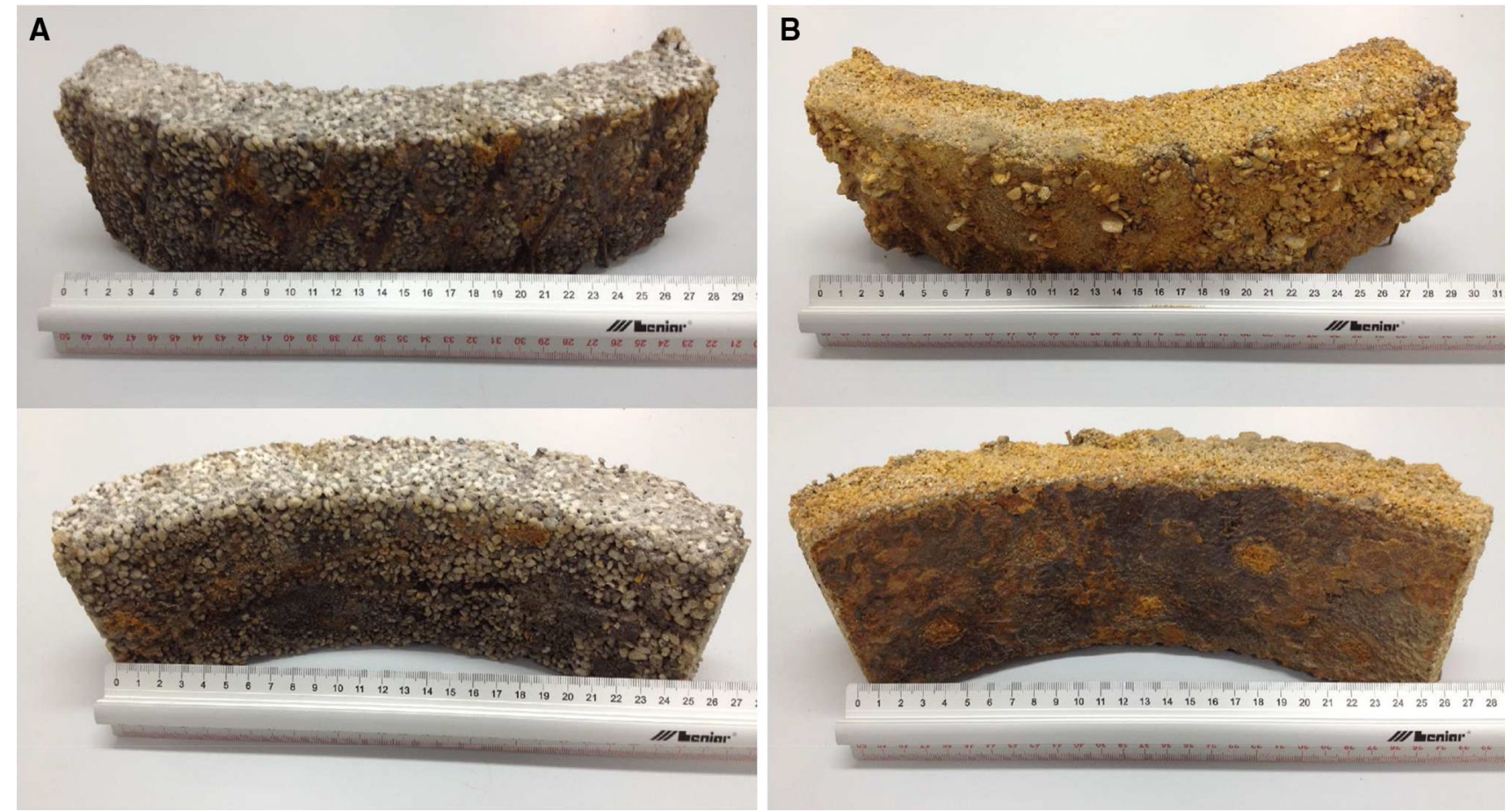

Fig. 5 Samples of the gravel coats of well; a NEW, b OLD W105 
Table 2 Electrical conductivity (EC), pH, total dissolved solids (TDS), chemical components (mg/L), and hardness in the leaching test of the new gravel coat and the gravel coat of well W105

\begin{tabular}{|c|c|c|c|c|c|c|c|c|c|c|c|}
\hline & Date (mm.yy) & $\mathrm{EC}(\mu \mathrm{S} / \mathrm{cm})$ & $\mathrm{Eh}(\mathrm{mV})$ & $\mathrm{pH}$ & TDS & $\mathrm{Na}^{+}$ & $\mathrm{K}^{+}$ & $\mathrm{Ca}^{2+}$ & $\mathrm{Mg}^{2+}$ & $\mathrm{Fe}^{2+}$ & $\mathrm{Mn}^{2+}$ \\
\hline NEW & 02.13 & 13.6 & 23.8 & 6.8 & 9.7 & 0.27 & 0.20 & 2.12 & 0.20 & 0.048 & 0.007 \\
\hline \multirow[t]{2}{*}{ OLD } & 02.13 & 259.0 & 40.0 & 6.5 & 184.0 & 1.53 & 1.58 & 44.30 & 5.68 & 0.075 & 0.043 \\
\hline & $\mathrm{HCO}_{3}^{-}$ & $\mathrm{Cl}^{-}$ & \multicolumn{2}{|c|}{$\mathrm{SO}_{4}{ }^{2-}$} & \multicolumn{2}{|c|}{$\begin{array}{l}\text { Total } \\
\text { hardness }\end{array}$} & & \multicolumn{2}{|c|}{$\begin{array}{l}\text { Carbonate } \\
\text { hardness }\end{array}$} & \multicolumn{2}{|c|}{$\begin{array}{l}\text { Non- } \\
\text { carbonate } \\
\text { hardness }\end{array}$} \\
\hline NEW & 0.5 & 2.9 & \multicolumn{2}{|c|}{1.9} & \multicolumn{2}{|c|}{6.1} & & \multicolumn{2}{|l|}{0.4} & \multicolumn{2}{|c|}{0.11} \\
\hline OLD & 27.0 & 4.9 & \multicolumn{2}{|c|}{109.0} & \multicolumn{2}{|c|}{134.0} & & \multicolumn{2}{|l|}{22.1} & \multicolumn{2}{|c|}{2.24} \\
\hline
\end{tabular}

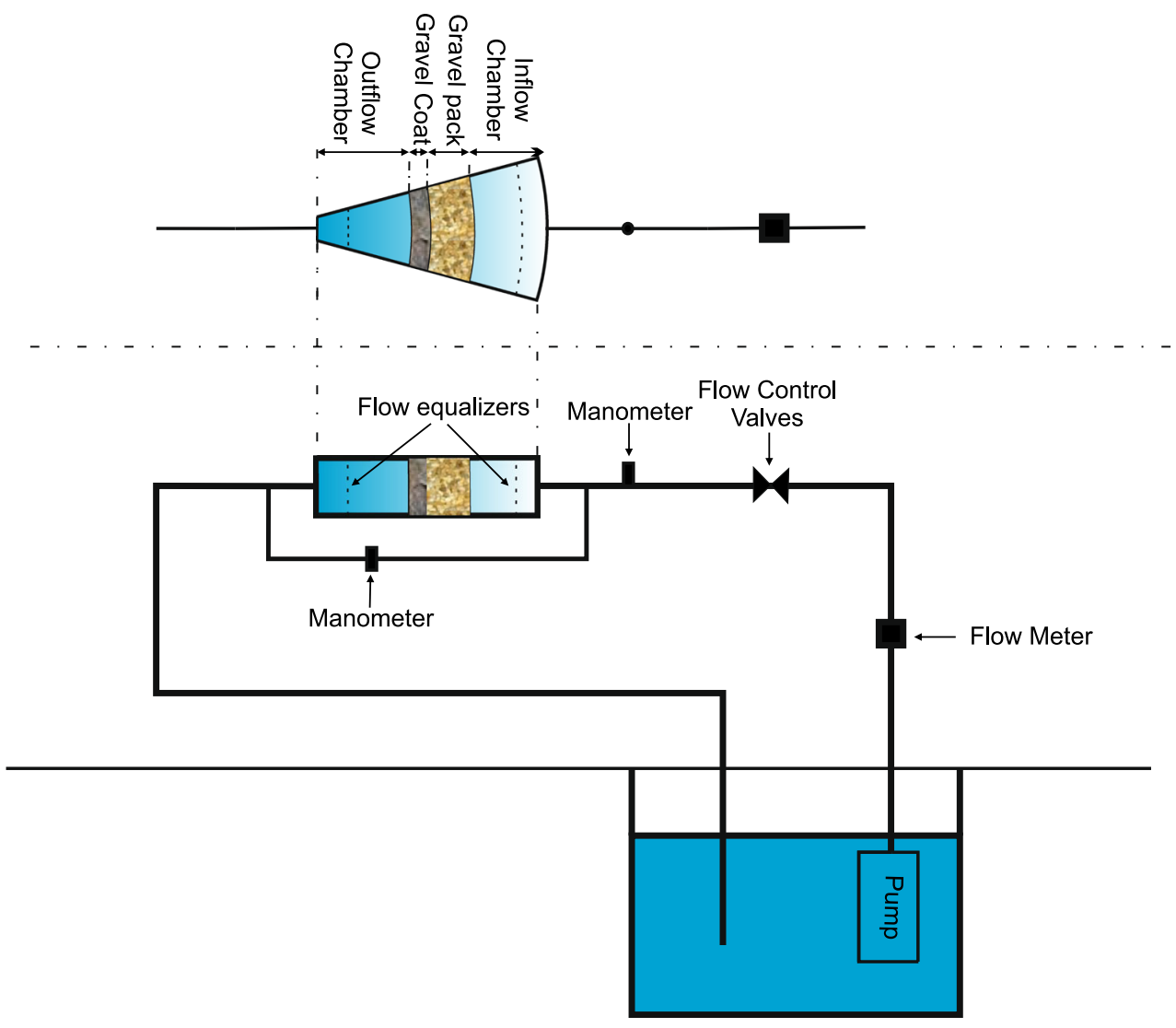

Fig. 6 Hydraulic test apparatus

taken at increasing flow rates and the pressure loss was recorded. Pressure and flow sensors transferred data to a computer, where they were archived and processed.

\section{Results and Discussion}

The static leaching tests showed that the old gravel coat sample had higher concentrations of all studied parameters, especially $\mathrm{SO}_{4}, \mathrm{HCO}_{3}, \mathrm{Ca}, \mathrm{Mn}$, and $\mathrm{Mg}$. These results corresponded to the water composition pumped out of well
W105. After 10 years of operation, the old gravel coat had a level of soluble solids almost 20 times greater than the new gravel coat, at about $184.3 \mathrm{mg} / 100 \mathrm{~g}$ of the dry weight of the gravel coat. The test results allowed us to determine the drawdown, apparent seepage velocity $v$, the effective velocity of the flow $v_{a}$, the Reynolds number $N_{R}$, and the well efficiency of individual gravel coats $E_{f}$ (Figs. 7, 8, 9).

In Fig. 7, the yield of the well per $\mathrm{m}^{2}$ of gravel coat represents the apparent seepage velocity $\left(\mathrm{v}_{\mathrm{f}}\right)$, which is a fictitious velocity of water filtration per cross-section unit calculated from Darcy's law (Bocheńska et al. 2002). The 


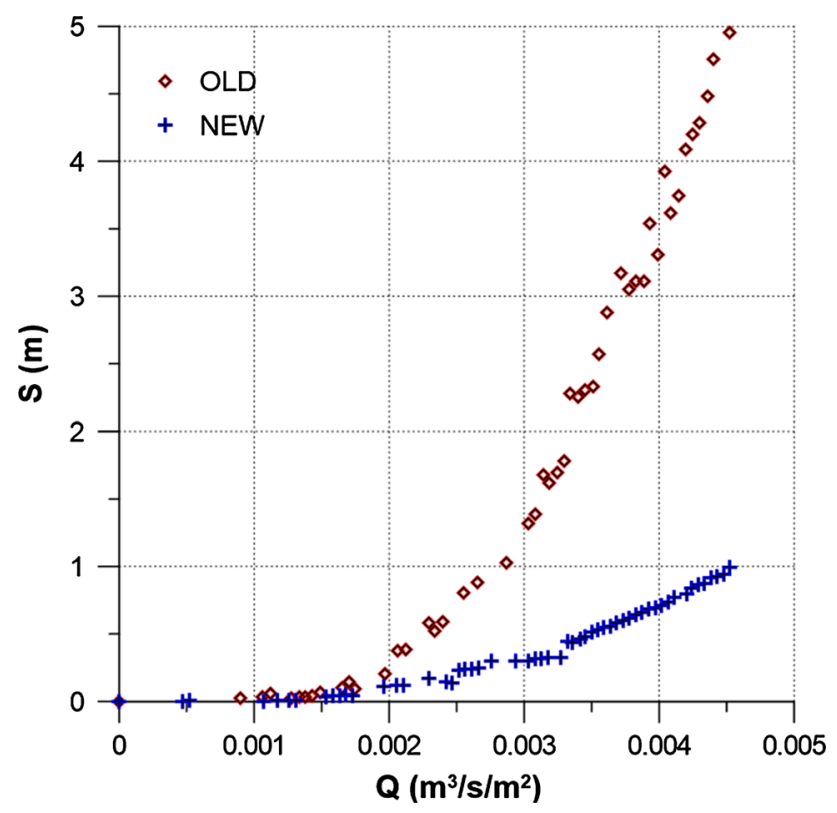

Fig. 7 The relationship of drawdown (S) and yield of well (Q) per $\mathrm{m}^{2}$ of gravel coat

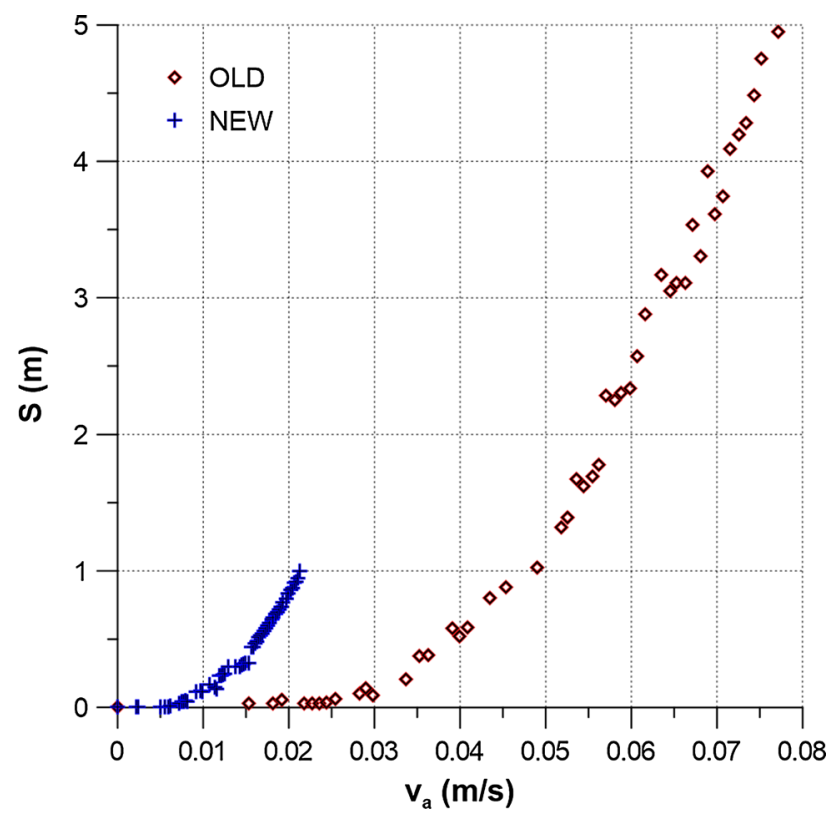

Fig. 8 The relationship of drawdown and effective water flow velocity through the NEW and OLD gravel coats

maximum measured drawdown for the same apparent seepage velocity were five times higher for the old gravel coat (Fig. 7). In other words, to get the same performance in the well, the head loss has to be five times greater in the old gravel coat vs the new. This has an impact on power consumption in pumping costs.

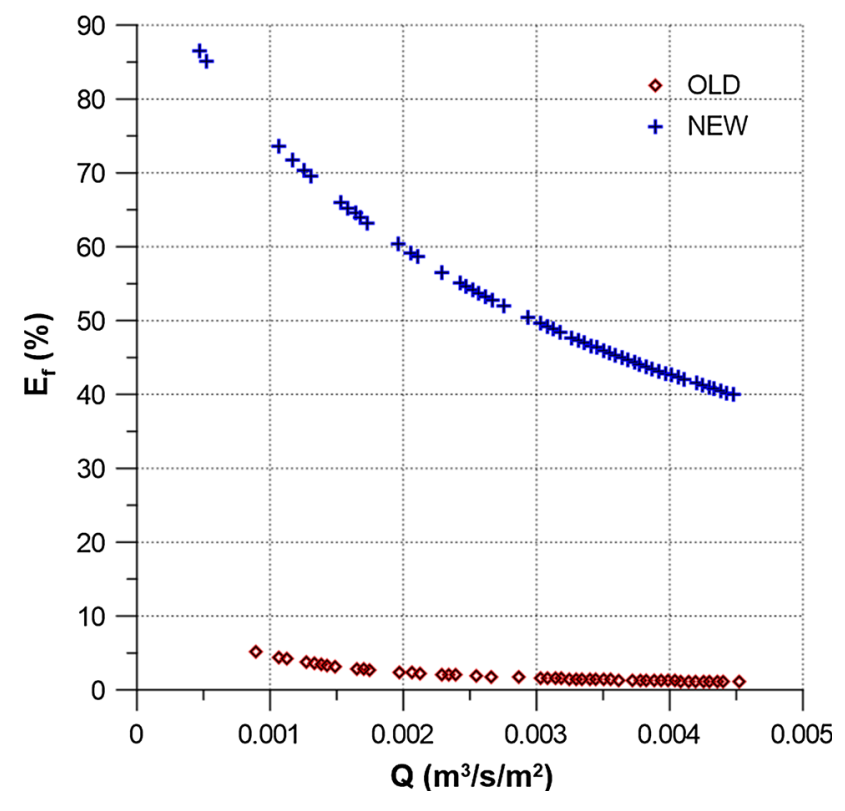

Fig. 9 The dependence of the new and old gravel coat efficiency to the yield of well $(\mathrm{Q})$ per $\mathrm{m}^{2}$ of gravel coat

A clear difference between new and old gravel coats can be seen in the effective velocity (Fig. 8), as determined from the formula (Kruseman and de Ridder 1991):

$v_{a}=\frac{Q}{n A}$

where $Q=$ volume rate of flow, $A=$ cross-sectional area normal to flow direction, and $n=$ porosity.

Thus, effective velocity expresses a real velocity of water filtration in the pore space (Bocheńska et al. 2002). The effective flow velocity was $0.02 \mathrm{~m} / \mathrm{s}$ for the new gravel coat sample for a drawdown of $1 \mathrm{~m}$. For a drawdown of $1 \mathrm{~m}$ for the old coat sample, the effective velocity was $0.08 \mathrm{~m} / \mathrm{s}$ due to the different porosities of the gravel coats.

In order to illustrate the differences in the hydraulic efficiency of the two gravel coats (Fig. 9), coefficients of hydraulic resistance were calculated using linear well-loss coefficient $B$ and non-linear well-loss coefficient $C$. The coefficients were determined using the results from the hydraulic test, by interpolation of the $S=f(Q)$ curves. Gravel coat efficiency $E_{f}$ was determined from the formula (Kawecki 1995):

$E_{f}=\frac{B Q}{B Q+C Q^{2}} \cdot 100 \%$

where $B Q=$ aquifer loss and $C Q^{2}=$ well loss.

As discussed above, the yield of the well per $\mathrm{m}^{2}$ of gravel coat refers to the apparent seepage velocity $\left(\mathrm{v}_{\mathrm{f}}\right)$. The new gravel coat achieved an efficiency of $40-87 \%$, for an apparent seepage velocity of $1.010^{-3}$ to $4.510^{-3} \mathrm{~m} / \mathrm{s}$, while 
the hydraulic efficiency of the old gravel coat did not exceed $5 \%$ over the entire operating range.

\section{Conclusions}

Analysis of historical data related to the operation of the dewatering wells indicates that in the early years of operation, well W105 was working with a yield significantly in excess of the theoretical safe yield. That situation likely initiated mechanical clogging, which was probably the main contributor to initial well yield deterioration. Over time, well-losses increased due to chemical clogging. Laboratory studies of the gravel coat taken from the well confirmed both mechanical and chemical clogging. Porosity of the gravel coat after 10 years of operation was approximately one-third the porosity of a new one.

The calculated hydraulic efficiency of the gravel coat recovered from the abandoned well was only a few percent, much less than the hydraulic efficiency of the new one. Extremely high hydraulic gradient in the gravel coat as well as high velocity flow could have caused disintegration of the gravel coat. Results of the investigation indicate that the pumping regime for new wells should not exceed the theoretical safe yield. The results presented herein are being used to select optimal productivity wells, in order to limit energy loss and improve the high efficiency life span of the wells.

Acknowledgments The authors thank PGE Mining and the Conventional Power Generation Group for their support of this research. The authors also thank Mr. Len Murray, President of Klohn Crippen Berger, for useful discussions and help in improving the manuscript.

Open Access This article is distributed under the terms of the Creative Commons Attribution 4.0 International License (http://crea tivecommons.org/licenses/by/4.0/), which permits unrestricted use, distribution, and reproduction in any medium, provided you give appropriate credit to the original author(s) and the source, provide a link to the Creative Commons license, and indicate if changes were made.

\section{References}

Bocheńska T, Dowgiałło J, Kleczkowski AS, Krajewski S, Macioszczyk A, Macioszczyk T, Małecka D, Rogoż M, Różkowski A, Sadurski A, Szczepański A, Witczak S (2002)
Słownik Hydrogeologiczny Publ, Państwowy Instytut Geologiczny, Warszawa, Poland [in Polish]

de Zwart A (2007) Investigation of clogging processes in unconsolidated aquifers near water supply wells. Ponaen \& Looyen BV, Delft

de Zwart BR, van Beek K, Houben G, Treskatis C (2006) Mechanische Partikelfiltration als Ursache der Brunnenalterung. Abb vwgw Bonn 57(9):32-37 [in German]

Dimkic M, Brauch HJ, Kavanaugh MC (eds) (2008) Groundwater management in large river Basins. Iwa Publ, London

Driscoll FG (1995) Groundwater and wells. Johnson Screens, Saint Paul

Gonzalez B (2013) Clogging of deep well infiltration recharge systems in the Netherlands. In: Martin R (ed) Clogging issues associated with managed aquifer recharge methods. IAH Commission on Managing Aquifer Recharge, Australia, pp 163-173

Houben G, Treskatis C (2007) Water well rehabilitation and reconstruction. McGraw Hill, New York

Kasenow M (2001) Applied ground-water hydrology and well hydraulics, 2nd edn. Water Resource Publications, LLC, Denver, pp $579-586$

Kawecki MW (1995) Meaningful interpretation of step-drawdown tests. Ground Water 33(1):23-32

Kovacs G, Ujfaludi L (1983) Movement of fine grains in the vicinity of well screens. Hydrolog Sci J 28(2):247-260

Kruseman GP, de Ridder NA (1991) Analysis and evaluation of pumping test data, 2nd edn. International Institute for Land Reclamation and Improvement, The Netherlands

Mishra PK, Kuhlman KL (2013) Unconfined aquifer flow theory: from Dupuit to present. Springer, New York, pp 185-202

Sawicki J (2000) The changes of natural infiltration of precipitation into aquifers the result of a deep mining groundwater drainage. Oficyna Wydawnicza Politechniki Wrocławskiej, Wrocław, pp 128-144 [in Polish]

Singer PC, Strumm W (1970) Acidic mine drainage: the ratedetermining step. Science 167(3921):1121-1123

Treskatis Ch, Volgnandt P, Wessollek H, Puronpää-Schäfer P, GerblRieger S, Blank KH (1998) Anforderungsprofile an den wirtschaftlichen Bau und Betrieb von Bohrbrunnen. Grundwasser 3(3):117-128

Vandersalm J, Smitt C, Barry K, Dillon P, Davidge S, Gornall D, Seear H, Ife D (2013) Potential for injection well clogging in an anoxic sandstone aquifer receiving fresh, deoxygenated but chlorinated injectant. In: Martin R (ed) Clogging issues associated with managed aquifer recharge methods. IAH Commission on Managing Aquifer Recharge, Australia, pp 34-49

Weidner Ch, Henkel S, Lorke S, Rude TR, Schuttrumpf H, Klauder W (2011) Experimental modelling of chemical clogging processes in dewatering wells. Mine Water Env 31(4):242-251

Williams EB (1981) Fundamental concept of well design. Groundwater 19(5):527-542

Zdechlik R, Kania J (2003) Hydrogeochemical background and distribution of indicator ion concentrations in the region of the Bełchatów lignite deposit. Contemp Probl Hydrogeol 11(2):327-334 